\title{
Reflections on \\ Latin American Development
}


THIS PAGE INTENTIONALLY LEFT BLANK 
Latin American Monographs, No. 8

Institute of Latin American Studies

The University of Texas 
THIS PAGE INTENTIONALLY LEFT BLANK 


\section{Reflections on \\ Latin American Development}

By Roberto de Oliveira Campos

Introduction by Benjamin Higgins

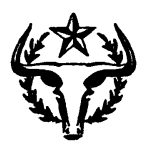

Published for the Institute of Latin American Studies by the University of Texas Press, Austin 
Library of Congress Catalog Card No. 67-64859 Copyright (1) 1967 by Roberto de Oliveira Campos All rights reserved 